\title{
ESTIMATIONS OF THE DECREASE IN EFFECTIVE BLOOD VOLUME WHEN PRESSURE BREATHING AT SEA LEVEL ${ }^{1}$
}

\author{
By J. P. HENRY, I. HENDRICKSON, E. MOVITT, AND J. P. MEEHAN
}

(From the Department of Physiology, University of Southern California, Los Angeles 7, California)

(Received for publication April 26, 1948)

Studies conducted in this laboratory and reported to the OSRD (1) as early as August, 1944, drew attention to the value of counter-pressurization of the extremities in preventing collapse when breathing at intermittent pressures of 30 to 40 $\mathrm{mm}$. Hg. Recent reviews of the physiology of pressure breathing $(2,3)$ comment on the tendency towards circulatory collapse during pressure breathing and suggest that the failure is probably associated with a decrease in effective circulating blood volume. This could be engendered by a pooling of blood in the congested veins of the extremities, by a loss of fluid due to filtration from the circulation under conditions of increased capillary hydrostatic pressure, or by a combination of both mechanisms. Fenn, Otis, and their collaborators (4) have measured the approximate amount of blood trapped in the leg veins during pressure breathing by a technique involving comparisons of a teeter-board and leg plethysmograph data. They conclude that during pressure breathing some 3 per cent of the total blood volume may be sequestered in the legs alone. Barach, et al. (3) have calculated the loss of fluid from the circulation during pressure breathing from measurements of changes in the oxygen capacity and the plasma protein concentrations of the blood. In men subjected to continuous pressure breathing at levels of $20 \mathrm{~cm}$. water for periods of less than one hour, the oxygen capacity data indicate a hemoconcentration of about 5 per cent, while the plasma protein data give a calculated fluid loss of 6.5 per cent.

Since both losses are associated with abnormal relations between the intravascular and tissue pressures in the extremities, it is theoretically possible

1 This work was performed under contract recommended by the Committee on Medical Research between the OSRD and the University of Southern California. It was reported in July, 1945, to the Committee on Aviation Medicine as Report No. 452. to decrease these losses by effective counter-pressurization of the extremities. Barach, et al. (3) find that fluid loss during pressure breathing can be diminished from 6.5 per cent to 2.3 per cent when the subjects are provided with tight-fitting counter-pressurization pants.

We have measured the extent of fluid loss during continuous pressure breathing at several pressure levels by means of changes in the hematocrit and hemoglobin values. Since the changes in the pressure gradient across the vascular walls in the extremities during pressure breathing is of a magnitude which might lead to distension and possible changes in the permeability of the vascular wall (cf. 5), plasma protein concentrations were determined and the tendency for protein leakage from the circulation calculated.

\section{METHODS}

Five male subjects in normal health and of ages ranging from 20 to 30 years were used. They were fitted with a full-face pressure breathing mask and a pressure vest of appropriate size and with tights snugly fitted over the legs and buttocks. The pressure breathing mask was supplied with a Linde exhalation valve and a standard check valve. After 30 minutes of rest in the sitting position, to decrease the effects of postural changes on the blood volume (6), 10-12 cc. blood were taken from a forearm vein after heating the arm for three minutes to avoid stasis. Continuous pressure breathing was then carried out for 30 minutes at pressure levels varying from 20 to $63 \mathrm{~mm}$. $\mathrm{Hg}$, and at the end of this time a second blood sample was taken from the back of the hand after heating to $47-48^{\circ} \mathrm{C}$. for three to five minutes. The building in which these experiments were carried out was air-conditioned, and the temperature was held at approximately $23^{\circ} \mathrm{C}$.

Hematocrits were determined in duplicate using the Wintrobe technique (7). Hemoglobin estimations were also made in duplicate by use of the acid hematin technique. The color developed was estimated with a KlettSummerson photoelectric colorimeter. Plasma protein concentrations were estimated in duplicate using the Mehl technique (8). Estimations were made immediately after 
drawing the blood into heparinized syringes. The results obtained are accurate to the order of plus or minus 1.0 2 per cent. On several occasions, radial arterial blood was taken in place of the heated hand vein specimen.

The per cent fluid loss was approximately from the hematocrit and the hemoglobin data according to the following equations :

$$
\begin{aligned}
& \text { Fluid loss }=1-\frac{\text { Control hemoglobin }}{\text { Experimental hemoglobin }} \\
& \text { Fluid loss }=1-\frac{\text { Control hematocrit }}{\text { Experimental hematocrit }}
\end{aligned}
$$

This calculation assumes an unchanged volume of circulating red blood cells, and therefore can yield only an approximation of the true changes in plasma volume.

Plasma protein leakage was calculated according to the equation presented by Landis and co-workers (5). Each subject was submitted to two or three estimations at each pressure in an attempt to confirm the values obtained. The following experimental combinations were employed: Mask only, mask and vest, and mask and vest with leg counter-pressure.

\section{RESULTS}

In Table I and Figure 1, the calculated fluid losses are presented in terms of percentage change in blood volume. Blood volume was adopted as the reference standard since the significance in terms of possible circulatory collapse of a rapid loss of 12 per cent of the blood volume is well recognized. This represents a one-pint transfusion donation from an average blood volume of $5000 \mathrm{cc}$. When no leg counter-pressure was used, the average pressure required to induce an 8 per cent change in blood volume in 30 minutes was $50 \mathrm{~mm} . \mathrm{Hg}$. The use of a jacket did not change this figure appreciably, but leg counterpressure provided approximately 20 per cent protection. The figures obtained are variable. This may be because the calculation of fluid loss from hematocrit and hemoglobin changes presupposes that the changed readings are due to fluid loss alone. Systemic fluctuations in the red cell count during the experiment will vitiate this assumption and it is probable that the disturbances induced by pressure breathing include such variations in red cell count (6). Because of these and other technical difficulties it was not possible to present consistent evidence in all subjects of the advantage derived from the use of experimental counter-pressurization of the legs. However, the trend toward a lower fluid loss when using leg protection is still apparent. The data for the hemoglobin de-

\begin{tabular}{|c|c|c|c|c|c|}
\hline $\begin{array}{l}\text { Pressure } \\
m m . H g\end{array}$ & Subject & Runs & $\underset{\substack{\text { hema- } \\
\text { tocrit }}}{\% \text { Fl. loss }}$ & $\begin{array}{c}\% \text { Fl. loss } \\
\text { hemo- } \\
\text { globin }\end{array}$ & $\begin{array}{l}\% \text { Protein } \\
\text { in filtrate }\end{array}$ \\
\hline
\end{tabular}

TABLE I

A. With mask only

\begin{tabular}{c|c|c|c|c|c}
\hline 0 & $\mathrm{C}$ & 1 & 0.5 & 1.0 & 6.7 \\
\hline 20 & $\mathrm{~A}$ & 4 & 1.5 & 2.3 & -2.7 \\
20 & $\mathrm{C}$ & 2 & 1.0 & 2.5 & -0.1 \\
20 & Avg. & 6 & 1.3 & 2.3 & -1.8 \\
\hline 30 & B & 1 & 3.3 & 5.9 & 7.2 \\
30 & C & 1 & 7.0 & 2.0 & $\frac{7}{7.2}$ \\
30 & Avg. & 2 & 5.1 & 3.9 & 7.2 \\
\hline
\end{tabular}

B. Mask and vest

\begin{tabular}{l|c|l|l|r|r}
\hline 20 & $\mathrm{D}$ & 1 & 0.0 & 0.5 & \multicolumn{1}{|c}{} \\
20 & $\mathrm{E}$ & 2 & 0.4 & 2.5 & 3.2 \\
20 & Avg. & 3 & 0.3 & 1.8 & 1.1 \\
\hline 30 & $\mathrm{~A}$ & 1 & 5.1 & 8.2 & 3.3 \\
30 & $\mathrm{C}$ & 1 & 3.3 & 4.0 & 1.1 \\
30 & $\mathrm{D}$ & 3 & 3.3 & 3.0 & -2.7 \\
30 & $\mathrm{E}$ & 1 & 3.0 & $\overline{4}$ & -7.4 \\
30 & Avg. & 6 & 3.5 & 4.2 & -1.9 \\
\hline 40 & $\mathrm{~A}$ & 2 & 6.5 & 9.3 & 1.7 \\
40 & $\mathrm{~B}$ & 2 & 5.8 & 5.0 & 1.7 \\
40 & $\mathrm{C}$ & 5 & 6.3 & 5.9 & -1.1 \\
40 & Avg. & 9 & 6.2 & 6.5 & 0.1 \\
\hline 53 & $\mathrm{~B}$ & 5 & 9.0 & 10.9 & 2.7 \\
53 & $\mathrm{C}$ & 2 & 8.7 & 7.0 & 1.8 \\
53 & Avg. & 7 & 8.9 & 9.8 & 2.4 \\
\hline
\end{tabular}

C. Mask, vest and pants

\begin{tabular}{c|c|c|r|r|r}
\hline 30 & $\mathrm{~A}$ & 2 & 4.6 & 7.4 & 1.1 \\
30 & $\mathrm{C}$ & 1 & 2.3 & 3.2 & -0.4 \\
30 & Avg. & 3 & 3.8 & 6.0 & 0.6 \\
\hline 40 & $\mathrm{~A}$ & 4 & 3.4 & 6.0 & 4.8 \\
40 & $\mathrm{~B}$ & 3 & 2.9 & 5.9 & 2.2 \\
40 & $\mathrm{C}$ & 2 & 5.0 & 5.3 & 0.5 \\
40 & Avg. & 9 & 3.6 & 5.8 & 3.0 \\
\hline 53 & $\mathrm{~A}$ & 1 & 5.7 & 8.0 & 0.4 \\
53 & $\mathrm{~B}$ & 5 & 7.8 & 8.2 & 2.6 \\
53 & $\mathrm{C}$ & 2 & 5.0 & 3.9 & -0.4 \\
53 & Avg. & 8 & 6.8 & 7.1 & 1.8 \\
\hline 63 & $\mathrm{~B}$ & 3 & 11.5 & 10.3 & 2.4 \\
63 & $\mathrm{C}$ & 1 & 7.4 & 5.7 & 0.3 \\
63 & Avg. & 4 & 10.5 & 9.1 & 1.9 \\
\hline
\end{tabular}

termination (cf. Figure 2) paralleled those for the hematocrits. Although more variable, they confirm the readings obtained and show that there is no consistent change in cell volume. Landis, et al. (5) point out that a change in cell volume should lead to a systematic discrepancy between the hemoglobin and hematocrit values. In practice, 


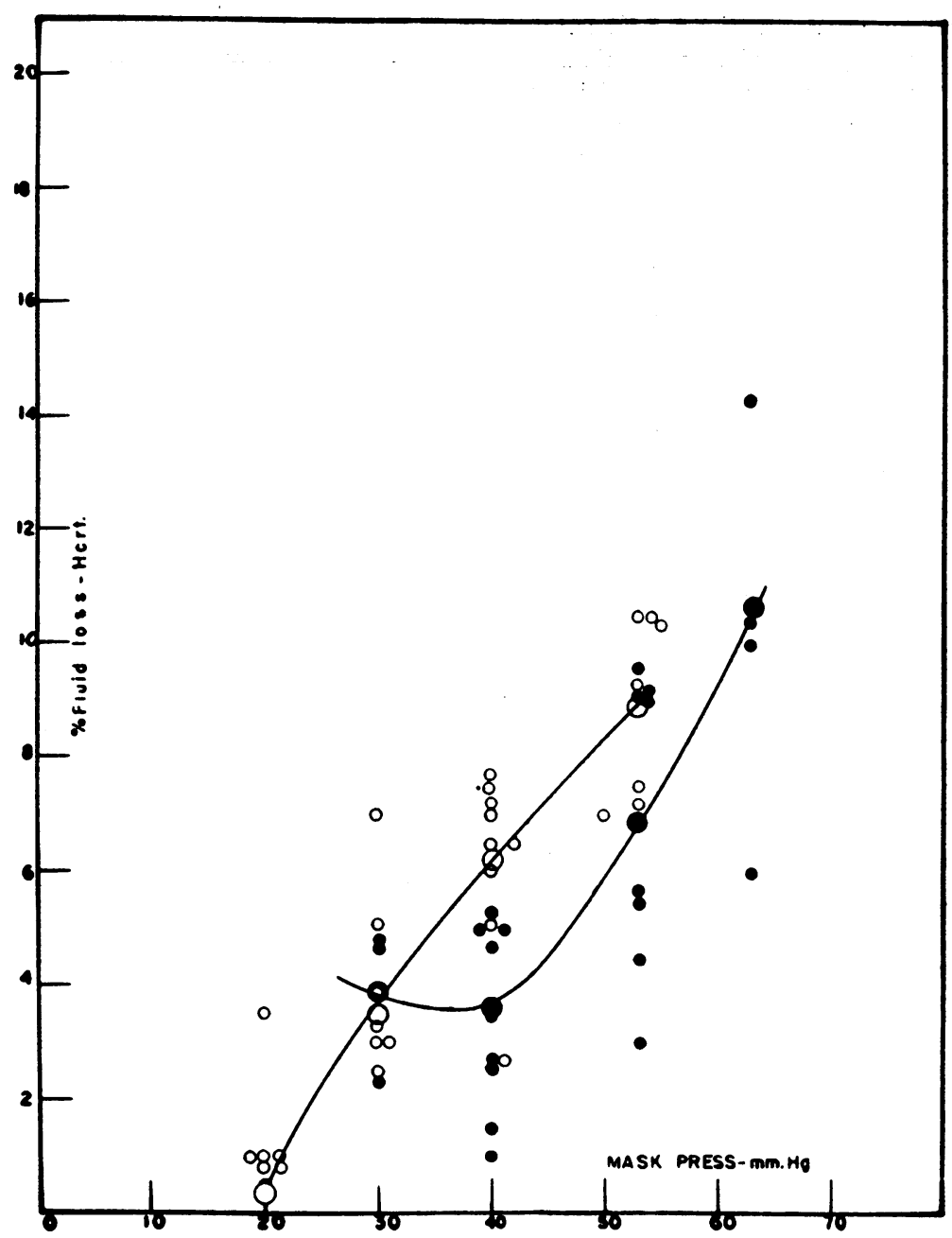

Fig. 1. Fluid Loss as a Function of Mask Pressure

Ordinates: per cent fluid loss calculated from hematocrit data; abscissa : mean mask pressure. Small open circles: individual data for subject wearing mask or mask and vest. Large open circles: average values for mask and mask and vest data at each pressure. Small solid circles: individual data for subjects wearing mask, vest and pants. Large solid circles: average values for subjects wearing mask, vest and pants at each pressure.

the deviations observed were random and therefore probably of experimental origin.

In Table I the calculated protein concentrations of the filtrates are given. There is an increase in protein leakage when the pressure breathing is done at the higher levels. In the case of subject $\mathrm{B}$, the data are moderately constant and are of 2 per cent protein in the filtrate. Subjects $A$ and $C$ give more variable data, including a number of negative values. Henry, et al. (9) have set forth a theoretical basis for the occurrence of these negative values.

Goldschmidt and Light (10) and others (11) have shown that the composition of arterialized hand vein blood does not differ significantly from that of true arterial blood. However, it was thought that in the circumstances of this experiment, the method of obtaining arterialized blood by heating the hand might be associated with some error. Congestion in the exposed unpressurized 


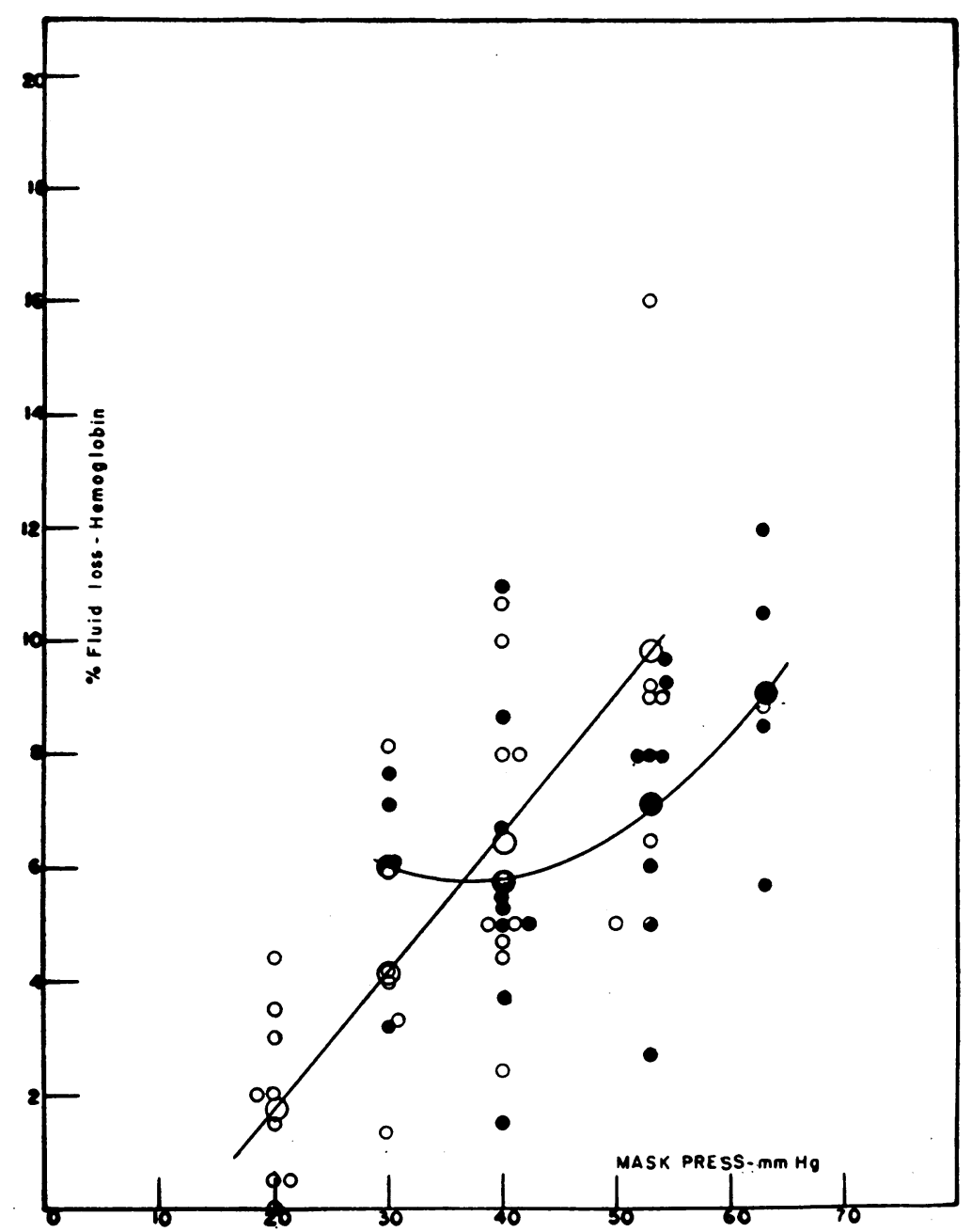

Fig. 2. Per Cent Fluid loss as a Function of Mask Pressure

Symbols as in Figure 1. Per cent fluid loss calculated on the basis of hemoglobin data.

arms might lead to an increase in local fluid loss and stasis in spite of the vasodilation, thus making the blood sample unrepresentative of the effective circulating blood volume. However, as shown in Table II, checks of arterial blood taken simultaneously with hand vein blood show no significant difference provided there has been adequate heating of the hand.

Figure 3 presents curves for subjects $A$ and $C$ showing the rate at which hemoconcentration develops when pressure breathing with only a vest and mask. The general form is the same in both cases and there is a return to normal within 30 minutes after pressure breathing was stopped.
However, there are interesting differences in detail. In subject $\mathrm{A}$, hemoconcentration proceeded at an approximately uniform rate throughout. In subject $C$, the rate of development was slower towards the end of the 30-minute period. Waterfield has noted individual variations in the fluid loss due to postural changes (6) and has attempted to correlate them with constitutional differences between the various subjects, including differences between the "firmness" of their tissues. Such inequalities in tissue turgor may also be the reason for the variations noted in the curves for progressive hemoconcentration when pressure breathing. 


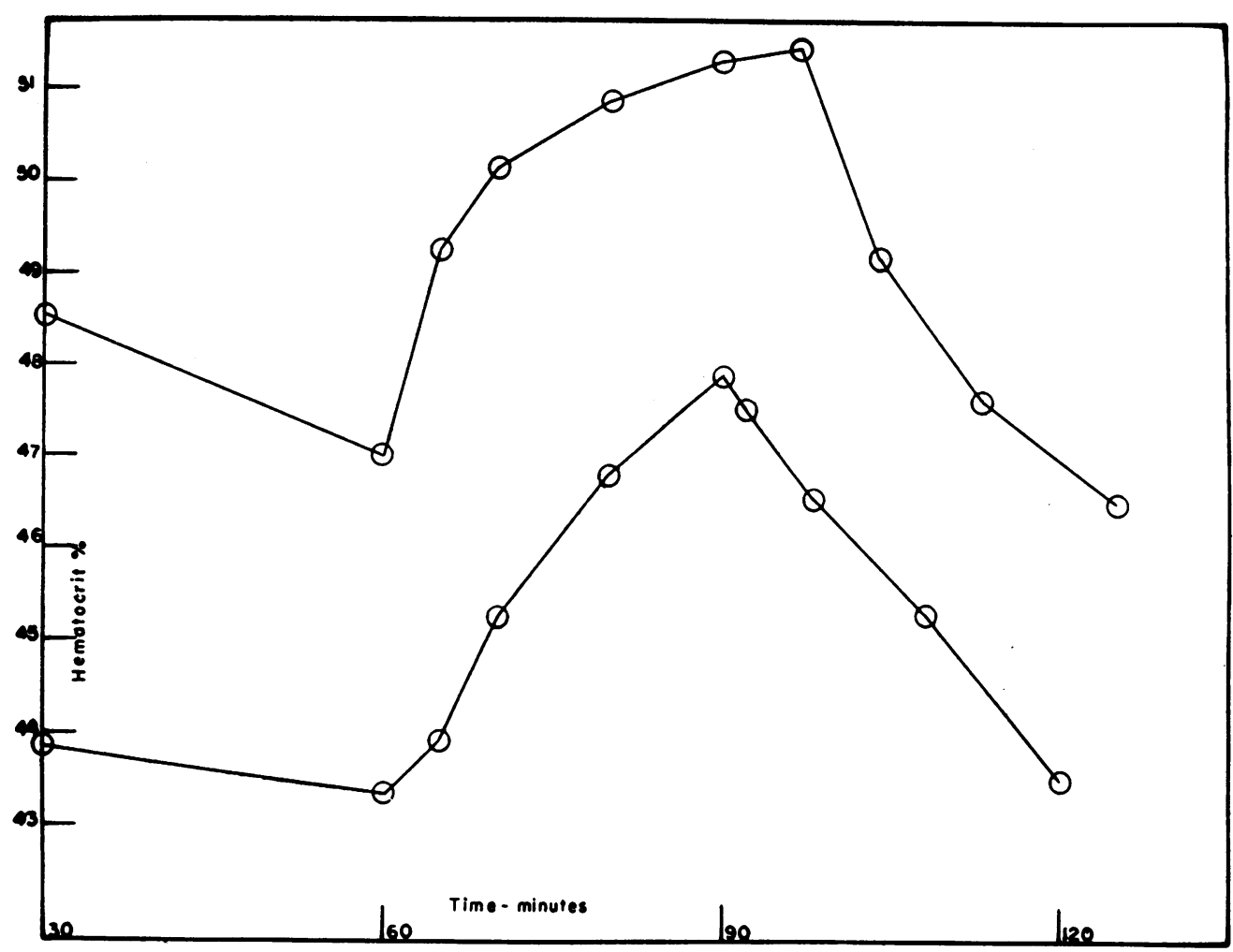

Fig. 3. Changes in Hematocrit Value during Pressure Breathing for Two Subjects Upper curve data relative to subject $C$, lower curve data relative to subject $A$.

TABLE II

Comparison of simultaneous arterial and arteriovenous blood after pressure breathing for 30 minutes at $50 \mathrm{~mm} . \mathrm{Hg}$

\begin{tabular}{|c|c|c|c|c|}
\hline \multirow{2}{*}{ Exp. } & & \multirow{2}{*}{ ' Hematocrit } & \multicolumn{2}{|c|}{ Hemoglobin } \\
\hline & & & Klett & $\begin{array}{l}\text { Grams/ } \\
100 \mathrm{cc} .\end{array}$ \\
\hline \multirow{2}{*}{1} & Arteriovenous & $\begin{array}{l}49.2 \\
49.3\end{array}$ & $\begin{array}{l}292 \\
293\end{array}$ & 15.5 \\
\hline & Arterial & $\begin{array}{l}49.1 \\
49.4\end{array}$ & $\begin{array}{l}284 \\
284\end{array}$ & 15.1 \\
\hline \multirow{2}{*}{2} & Arteriovenous & $\begin{array}{l}49.0 \\
49.2\end{array}$ & $\begin{array}{l}267 \\
267\end{array}$ & 14.3 \\
\hline & Arterial & $\begin{array}{l}49.0 \\
49.0\end{array}$ & $\begin{array}{l}268 \\
267\end{array}$ & 14.35 \\
\hline \multirow{2}{*}{3} & Arteriovenous & $\begin{array}{l}50.7 \\
50.1\end{array}$ & $\begin{array}{l}312 \\
315\end{array}$ & 16.6 \\
\hline & Arterial & $\begin{array}{l}50.0 \\
50.0\end{array}$ & $\begin{array}{l}305 \\
312\end{array}$ & 16.3 \\
\hline
\end{tabular}

\section{DISCUSSION}

Fenn, et al. (4) have shown that about $300 \mathrm{cc}$. of blood are displaced into the legs by pressure breath- ing at $23 \mathrm{~mm} . \mathrm{Hg}$. Ebert and Stead (12) showed that the application to one arm and both legs of pressure cuffs inflated to diastolic pressure, i.e., $70-100 \mathrm{~mm}$. $\mathrm{Hg}$ for seven to 10 minutes, results in a loss of blood volume of the order of $700 \mathrm{cc}$. Their data suggest that not more than one-third of this loss was due to the accumulation of fluid in the tissues. The remaining volume change they considered to be due to unchanged blood pooled in the peripheral veins.

A smaller ratio (of the order of $1: 1$ ) between the loss due to venous pooling and that due to increase in tissue fluid has been observed by Turner, Newton, and Haynes (13) in their studies of the swelling of the legs in the erect posture. If this lower ratio also applies to the events when pressure breathing, then the frequency with which syncope occurs when breathing at pressures of 50 $\mathrm{mm}$. $\mathrm{Hg}$ can be readily explained. At this pressure, the average change in blood volume in the course of 20 to 30 minutes is 8 per cent. This represents a fluid loss of $400 \mathrm{cc}$. in a subject having the average blood volume. The addition of a fur- 
ther 400-500 cc., representing blood pooled in the veins, gives a value of $800-900 \mathrm{cc}$. for the total loss in effective blood volume. This is enough to bring the average subject to the verge of collapse even when he is not anoxic. Similar estimations would give a total loss of the order of $300-400 \mathrm{cc}$. for pressures of $30 \mathrm{~mm}$. $\mathrm{Hg}$. This figure might help to account for the frequency with which syncope occurs in the anoxic subject when breathing at this lower pressure with a mask alone.

Objective evidence of the protection against collapse afforded by the use of counter-pressure clothing is given by the average decrease of approximately 20 per cent noted in the fluid loss for pressures in the range $40-60 \mathrm{~mm}$. $\mathrm{Hg}$. It would be desirable to demonstrate that this decrease in fluid loss is accompanied by a reduction in the extent of venous pooling.

\section{SUM MARY}

1. Pressure breathing for 30 minutes at $30 \mathrm{~mm}$. $\mathrm{Hg}$ at sea level leads, in the average subject, to a calculated loss into the tissues of 4 per cent of the blood volume. Raising the pressure to $53 \mathrm{~mm}$. $\mathrm{Hg}$ doubles this fluid loss.

2. The use of a pressure jacket greatly increases comfort but does not decrease the fluid loss significantly. The use of counter-pressure on the legs decreases the fluid loss by about 20 per cent.

3. Counter-pressurization of the limbs is discussed as a method for minimizing the decreases in effective circulating blood volume during pressure breathing.

\section{BIBLIOGRAPHY}

1. Drury, D. R., and Scott, G. H., Investigations in aviation physiology with particular attention to the effects of acceleration, decompression, anoxia, and cold and methods to combat these effects. Progress Report No. 7, OEMcmr-288, April, 1944.

2. Barach, A. L., Fenn, W. O., Ferris, E. B., and Schmidt, C. F., The physiology of pressure breathing. J. Aviation Med., 1947, 18, 73.

3. Barach, A. L., Eckman, M., Ginsburg, E., Rumsey, C. C., Korr, I., Eckman, I., and Besson, G., Studies on positive pressure respiration. I. General aspects and types of pressure breathing. II. Effects on respiration and circulation at sea level. J. Aviation Med., 1946, 17, 290.

4. Fenn, W. O., Otis, A. B., Rahn, H., Chadwick, L. E., and Hegnauer, A. H., Displacement of blood from the lungs by pressure breathing. Am. J. Physiol., 1947, 151, 258.

5. Landis, E. M., Jonas, J., Angevine, M., and Erb, W., The passage of fluid and protein through the human capillary wall during venous congestion. J. Clin. Invest., 1932, 11, 717.

6. Waterfield, R. L., The effects of posture on the circulating blood volume. J. Physiol., 1931, 72,110.

7. Wintrobe, M. M., A simple and accurate hematocrit. J. Lab. \& Clin. Med., 1929, 15, 287.

8. Mehl, J., The biuret reaction of proteins in the presence of ethylene glycol. J. Biol. Chem., 1945, 157, 173.

9. Henry, J. P., Goodman, J., and Meehan, J. P., Capillary permeability in relation to acute anoxia and to venous oxygen saturation. J. Clin. Invest., 1947, 26, 1119.

10. Goldschmidt, S., and Light, A., A method of obtaining from veins blood similar to arterial blood in gaseous content. J. Biol. Chem., 1925, 64, 53.

11. Meakins, J., Dautrebande, L., and Fetter, W., The influence of circulatory disturbances on the gaseous exchange of the blood. IV. The blood gases and circulation rate in cases of mitral stenosis. Heart, 1923, 10, 153.

12. Ebert, R. O., and Stead, E. A., The effect of the application of tourniquets on the hemodynamics of the circulation. J. Clin. Invest., 1940, 19, 561.

13. Turner, A. H., Newton, M. I., and Haynes, F. W., The circulatory reaction to gravity in healthy young women. Evidence regarding its precision and its instability. Am. J. Physiol., 1930, 94, 507. 